\title{
Promotion of Cultural Tourism in Sri Lanka with Special Reference to the North Central Province
}

\author{
WIJITAPURE WIMALARATANA \\ Department of Economics, University of Colombo, Sri Lanka. \\ wwimalar@yahoo.co.uk,wimala@econ.cmb.ac.lk
}

\begin{abstract}
ARTICLE INFO
ABSTRACT

Received:

Sri Lanka is an island in the Indian Ocean located to the south of India and separated from Indian subcontinent by a small straight. The island has been one of the major tourist attractions since antiquity. End of the protracted civil war is a blessing for the recent surge of tourist arrival and the rapid expansion of tourism facilities on the island. Although small, the island is rich in religious and cultural diversity with an immense attraction to the tourist. Buddhism is the main religion of the overwhelming majority of people even though Hinduism, Christianity and Islam are practiced side by side by several followers. The rich cultural heritage rotating around the religious practices, tolerance and beliefs ranges from historical monuments and ancient cities through meditation, yoga, folk music and dances, festivities, ceremonies and rituals. Special sites with multi-religious attractions reflect the diversity and uniqueness of a rich culture. North

Keywords: culture Central province is rich in religious and cultural resources than any Buddhism other province in Sri Lanka. Only a small fraction of these vast historical sites religion tourist resources has been utilized by the tourism industry so far. The promotion of the religious and cultural tourism products in the province will open new avenues for tourists as well as many people of the province.
\end{abstract}




\section{INTRODUCTION}

Sri Lanka, a mango fruit or tear drop shaped island in the Indian Ocean, is located just below the southernmost tip of India. It is separated from the Indian subcontinent by the thin Palk Strait and Gulf of Mannar. The island is also known as Heladiva, Taprobane, Ceylon, the Island of Serendipity or Pearl of Asia. It lies just above the equator between $5^{\circ} 55^{\prime} \mathrm{N}$ and $9^{\circ} 55^{\prime} \mathrm{N}$ and between the eastern longitudes $79^{\circ} 42^{\prime}$ and $81^{\circ} 52^{\prime}$. Sri Lanka has a total area of $65,610 \mathrm{sq} \mathrm{km}(25,332 \mathrm{sq}$ miles) with total coastline of $1,340 \mathrm{~km}$ (833 miles). The maximum length and width of the country is $435 \mathrm{~km}$ and $225 \mathrm{~km}$ respectively. It is a tropical island with the influence of sea breeze, rain, and land elevation to its climatic conditions. The annual daytime average temperature in the island as a whole varies from the lowest $28^{\circ} \mathrm{C}$ to the highest $32^{\circ} \mathrm{C}$. The mean temperature of the island changes from a cold low of $16^{\circ} \mathrm{C}$ in Nuwara Eliya in the central hilly lands to a high of $32^{\circ} \mathrm{C}$ in Trincomalee on the northeast coast.

The annual rainfall distribution is used to divide Sri Lanka into three major agroclimatological zones as Wet Zone in the southwestern region including central hill country; Dry Zone covering predominantly northern, north central, deep south and eastern parts of the country and Intermediate Zone running between the two major climatic zones. The dry zone covers $63.5 \%$ of the land mass of the country while wet zone and intermediate zone cover $23.2 \%$ and $13.3 \%$ respectively. All the major colonial plantation crops - tea, rubber and coconut - are virtually found in the wet zone while huge tracts of rice fields are located in the dry areas of the country. The mixed crop garden consisting of fruits, vegetables, spices and other perennial crops is a common characteristic everywhere in the island even though there are regional variations of products. Administratively the island is divided into nine provinces as the first tier and 25 districts as the second tier. A district is again divided into divisional secretary (DS) divisions and it is subdivided into grama niladari (GN) divisions, the smallest administrative division. There are 330 DS divisions and 14,022 GN divisions in the country. In addition, the country has 23 municipalities and 41 town councils (Department of Census and Statistics, 2012).

The island was home to some 7.5 million people in 1950, and the number increased to 20.9 million by 2011. Annual average population growth rate during the same period has declined from $3.3 \%$ to $1 \%$. The percentage of rural population in 1950 stood at $84.7 \%$ while urban population was $15.3 \%$. This composition has only changed 
marginally over a long period of six decades as the country has a rural sector friendly settlement pattern. The population density, however, has increased from 126 to 333 persons per square kilometer during this period of time (Central Bank of Sri Lanka 2011).

Sri Lanka has gradually transformed from a low income country to a lower middle income country over the past sixty years or so. Per capita GDP of the island was US $\$ 114$ in 1950 and increased to US $\$ 2,836$ by 2011 , adding roughly US $\$ 40$ to per capita income every year during this period of time (Central Bank of Sri Lanka 2011). Poverty has been the most disturbing factor of the Sri Lankan society in the past 60 years, and its pressure will check the delicate balance of the society in years to come. Post-independent livelihood development programs, especially in the domestic agricultural sector, and various welfare policies have reduced the poverty to a great extent. Household income and expenditure surveys suggest that national poverty headcount ratio stood at 26.1 in 1990-1991 and subsequently declined to 8.9 in 2009-2010 (Department of Census and Statistics 2012). The overall socioeconomic development of the island is better compared to its per capita income and many other developing countries. Sri Lanka ranks 97 in Human Development Index (HDI) among 187 countries and territories worldwide (UNDP 2011).

Sri Lanka is a multicultural, multireligious, multiethnic, and multilinguistic country where all have freedom to follow any religion or culture and use any language. The objective of this paper is to examine the potential of religious and cultural tourism promotion in Sri Lanka paying special attention to the resource heritage and its regional diversity. The North Central Province (NCP), the cradle of Sri Lankan culture and religion with the recorded history from $6 \mathrm{C} \mathrm{BC}$, is selected for this purpose. Secondary data as well as the field observations and interviewing of key informants are the major sources of information for the paper.

\section{TOURISM IN SRI LANKA}

A dedicated tourism promotion strategy was absent in the country for a long period of time, even though some visitors came to the island by their own initiatives in the past. The economy under the British rule rotated around the profitable plantation sector and paid little or no attention to promotion of the tourism sector until the very end of its rule. The colonial administration formed the Government Tourist Bureau in 1937 to provide facilities and services to the large volume of cruise passengers between the East and the 
West through Colombo port. It is estimated that over one hundred thousand passengers received the services and facilities of the Colombo port annually during this period of time. The onset of Second World War, however, decreased the number of passenger ships call at Colombo port dramatically and thereby dislodged the need of the Tourist Bureau.

The revival of the Tourist Bureau was visible with the political independence of 1948 . The mode of tourist transport has shifted from sea cruise to airplane in the meantime, and the country was not prepared for this change. The expansion of the only international airport in Colombo was carried out only in second half of the 1960s, and new terminal building was opened in 1968. The Sri Lanka hotel school as a public entity was incorporated to provide skilled manpower for the industry in 1964, and the Ceylon Tourism Board was formed in 1966. The newly formed Ceylon Tourism Board made an all-out effort with many innovative strategies to promote the industry. It was a selfdefeating exercise, as government was following inward looking and anti-private sector policies up to the economic liberalization of 1977. The evil effect of the civil unrest, however, checked the progress of the tourism industry until the end of civil war in 2009. The Tourism Development Authority was formed in 2005 to promote the industry during the civil war period.

Now the tourism industry is recording unprecedented rapid progress in the island at the end of the civil war. Local and foreign investment is constantly flowing into the sector although religious and cultural tourism is not promoted as a special product of the industry. Tourist arrivals are expected to rise exponentially in the near future, as the country is currently enjoying a new era of political stability and security. Similarly, old tourist attractions in the war-ravaged areas have been added to the tourism product basket. Interestingly, the NCP is located bordering to the civil war-affected Northern and Eastern provinces. The peace has brought a special advantage to the NCP to promote its cultural and religious heritage.

Table 1: Performance of Tourism Sector of Sri Lanka

\begin{tabular}{ccccc}
\hline Year & $\begin{array}{c}\text { Tourist } \\
\text { Arrivals (No) }\end{array}$ & $\begin{array}{c}\text { Per Capita Tourist } \\
\text { Receipts (Rs.mil) }\end{array}$ & $\begin{array}{c}\text { Gross Tourist } \\
\text { Receipts (Rs.mil) }\end{array}$ & $\begin{array}{c}\text { Annual Room } \\
\text { Occupancy Rate } \\
\text { \% }\end{array}$ \\
\hline 2001 & 336,794 & 56,008 & 18,863 & 42.1 \\
2002 & 393,171 & 61,556 & 24,202 & 43.1
\end{tabular}




\begin{tabular}{lllll}
2003 & 500,438 & 65,536 & 32,810 & 53.2 \\
2004 & 566,202 & 75,355 & 41,666 & 59.3 \\
2005 & 549,308 & 66,223 & 36,377 & 45.4 \\
2006 & 559,603 & 76,100 & 42,586 & 47.8 \\
2007 & 494,008 & 86,175 & 42,571 & 46.2 \\
2008 & 438,475 & 84,598 & 37,094 & 43.9 \\
2009 & 447,890 & 89,605 & 40,133 & 48.4 \\
2010 & 654,476 & 99,344 & 65,018 & 70.1 \\
2011 & 855,975 & 107,393 & 91,926 & 77.1 \\
\hline
\end{tabular}

Sources: Central Bank Annual Reports, Sri Lanka Tourism Development Authority

Tourist arrivals as well as tourist receipts and hotel room occupancy rate have increased since the end of the civil war. The trend will continue further along with new investments in the industry and promotional campaigns even though the economic difficulties in Europe and some other countries are intermittently hindering this progress. The growing economies in Asia, especially China and India, give an extra leverage to the industry. Interestingly, tourists from Asia are closer to the culture and religious tourism products of Sri Lanka even though they do not have the same curiosity as the Western tourists. A certain percentage of inbound tourists go to the NCP and other areas in which cultural and religiously resources are in abundance.

Table 2: Tourist Arrivals by Purpose of Visits

\begin{tabular}{llllllll}
\hline \multirow{2}{*}{ Year } & \multicolumn{2}{c}{ Leisure } & \multicolumn{2}{c}{ Business } & \multicolumn{2}{c}{ Others } & \\
\cline { 2 - 6 } & \multirow{2}{*}{ Arrival } & Percentage & Arrival & Percentage & Arrival & Percentage & \\
\hline 2001 & 300,545 & 89.23 & 22,677 & 6.73 & 13,572 & 4.02 & 336,794 \\
2002 & 335,898 & 85.43 & 36,793 & 9.35 & 20,480 & 5.20 & 393,171 \\
2003 & 404,327 & 80.79 & 45,558 & 9.10 & 50,553 & 10.10 & 500,438 \\
2004 & 442,534 & 78.15 & 59,961 & 10.59 & 63,707 & 11.25 & 566,202 \\
2005 & 382,321 & 69.60 & 92,879 & 16.90 & 74,108 & 13.49 & 549,308
\end{tabular}




\begin{tabular}{llllllll}
2006 & 392,766 & 70.18 & 96,981 & 17.33 & 69,856 & 12.48 & 559,603 \\
2007 & 331,238 & 67.05 & 52,116 & 10.54 & 110,654 & 22.39 & 494,008 \\
2008 & 321,079 & 73.22 & 37,261 & 8.49 & 80,135 & 18.27 & 438,475 \\
2009 & 358,188 & 79.97 & 38,473 & 8.58 & 51,229 & 11.43 & 447,890 \\
2010 & 516,538 & 78.92 & 83,270 & 12.72 & 54,668 & 8.35 & 654,476 \\
\hline
\end{tabular}

Sources: Central Bank Annual Reports, Sri Lanka Tourism Development Authority

Overwhelming majority of tourists is coming for leisure purpose even though percentage has fallen gradually. Those who are coming for business and other purposes have risen in recent years. There is no special category for cultural and religious tourism sector. It is not difficult to assume that a certain percentage of leisure tourists and tourists with other purposes visit culturally and religiously important places. All tourists, however, unintentionally get some exposure to the local culture and religious practices while they stay in the island.

\section{RELIGION AND CULTURE OF SRI LANKA}

Sri Lanka has three major communities as Sinhalese, Tamil and Muslim. Authentic historical records suggest that the modern civilization of Sri Lanka as commencing from $544 \mathrm{BC}$ on the basis of the arrival of Sinhala-speaking people from Bengal of North East India to the island inhabited by primitive people. This conquest brought a considerable number of people into the island from their ancestral land possessing admirable skills, knowledge and culture. History suggests that within a few years of their arrival, Sinhalaspeaking people brought in their wives as well as craftsmen from Tamil-speaking South Indian regions.

Since very early time, south Indian people speaking Tamil, Malayalam, Kanarese or Telugu reached the island either as invaders or as peaceful immigrants. The island received much more influence from Tamil-speaking people than the rest of the South Indians. Colombo, the current administrative and commercial hub of Sri Lanka, became a Muslim trading settlement in about $8^{\text {th }}$ century $\mathrm{AD}$, and these traders married Sinhalese women to become members of Sinhala-Tamil family. All those three communities must have mixed with primitive people who lived in the island as the owner of the land before all others. 
The civilization of the island from the 6th century $\mathrm{BC}$ to the middle of the 13th century $\mathrm{AD}$, before the kingdom was shifted to the wet zone, is invariably referred to as the ancient period, Anuradhapura-Polonnaruwa or Rajarata periods. The civilization of this period was essentially that of the dry zone. The people lived in isolated villages, produced their own food and most of their necessities, and depended little on the rest of the world. Many features of the island's present culture and religions have their roots in these ancient periods.

The wet zone civilization of the island runs from $1235 \mathrm{AD}$ until 1815, when the entire island became a British colony. This is also known as medieval period and the islanders had to share its administration with the Portuguese, the Dutch and the British, in that order, during this period. The Portuguese period of the country, from their initial landing on the island's coast, lasted from 1505 to 1658 . The Dutch administration of the island goes roughly from 1658 to 1796 . Both Portuguese and Dutch regimes were confined to a narrow coastal belt of the island and the hinterland remained under the Sinhalese kings. While the Portuguese and the Dutch were keeping their grip on the maritime provinces, the Sinhalese kings ruled the most of hinterland. For much of the time there was a thorny relationship between the Sinhalese rulers and the European administrators of the coastal belt. The British ruled the entire island nearly one and half centuries from 1815 to 1948 . The cultural, political and socioeconomic transformation of the country under their rule was extremely profound and unprecedented one.

Buddhism was introduced to the island in the 3rd century BC by Emperor Asoka of India and it became the religion of Sinhalese community. The Buddhism ushered the Sinhalese culture through a higher ground and finally it became the Sinhalese-Buddhist culture. The Sri Lankan society received the influence of Hinduism since early time of its recorded history. Tamil-speaking people came to the island during the ancient periods with Hinduism and Tamil culture from South India. The Muslim community settled down on the island with Islamic religion and its culture in the 8th century. The Sri Lankan society received European influence since the beginning of the 16th century. It brought far-reaching changes to the society, culture, administration, and economy and judiciary system of the country. They introduced a new religion, the Christianity, to the island. A considerable percentage of Sinhalese and Tamil communities with Buddhist and Hindu religious background converted to the Christianity during the European period. The European culture, however, cut across the entire society even though there are geographical variations, making irreversible changes to a centuries-old society. This 
was further enhanced by the post-independent international relations and globalization forces.

\section{NORTH CENTRAL PROVINCE}

The island was divided into three major areas as Ruhunu, Maaya, and Pihiti prior to the European intervention in its affairs. The stretch of landmass comes under the modern NCP belonged to the Rajarata (the land of king) or to the Pihiti Rata during the preEuropean periods. This land area was home to five kingdoms as Tambapanni, Upatissa, Anuradhapura, Sigiriya, and Polonanaruwa in that order. The NCP, as a separate administrative unit, was created in 1873 by the British administration. The dividing lines of the British rule have not essentially reflected the native dividing lines. As a result, certain historical areas such as Sigiriya and Tambapanni are not parts of the current NCP even though they belonged to Rajarata or Pihiti Rata under the native divisions.

The NCP with an area of $10,714 \mathrm{~km}^{2}$ is the largest province of the country covering $16.31 \%$ of the land area of the island. The province consists of two administrative districts as Anuradhapura $\left(7,128 \mathrm{~km}^{2}\right)$ and Polonnaruwa $\left(3,403 \mathrm{~km}^{2}\right)$ and 29 DS divisions, 989 GN divisions, 3,742 villages, and two municipal councils as Anuradhapura Municipality and recently demarcated Polonnaruwa Municipality. Two districts and two municipal councils have been named after the two olden major kingdoms of the province. Two municipal councils are considered as capitals of these districts, and ruins and historical attractions of the two olden kingdoms are mostly concentrated in and around those municipalities.

Anuradhapura Kingdom (4C BC-11C AD): The beginning of the ancient city of Anuradhapura first as a simple village and thereafter a fully-fledged city goes back to the arrival of king Vijaya in the $6^{\text {th }}$ century BC. One of his ministers called Anuradha built a village close to the bank of the Malwathu River and it was named as Anuradha village during that period. King Pandukabhaya (437-367 BC) made this prosperous village as his capital and turned it into a city with necessary facilities of the day.

"The city [Anuradhapura] is one of the principal shrines of Buddhism. The cutting from the fig tree of Buddha, brought there in the 3rd century BC, has flourished and, today, the Bodhi tree spreads out over the centre of the site from a sanctuary near the Brazen Palace" (UNESCO). 

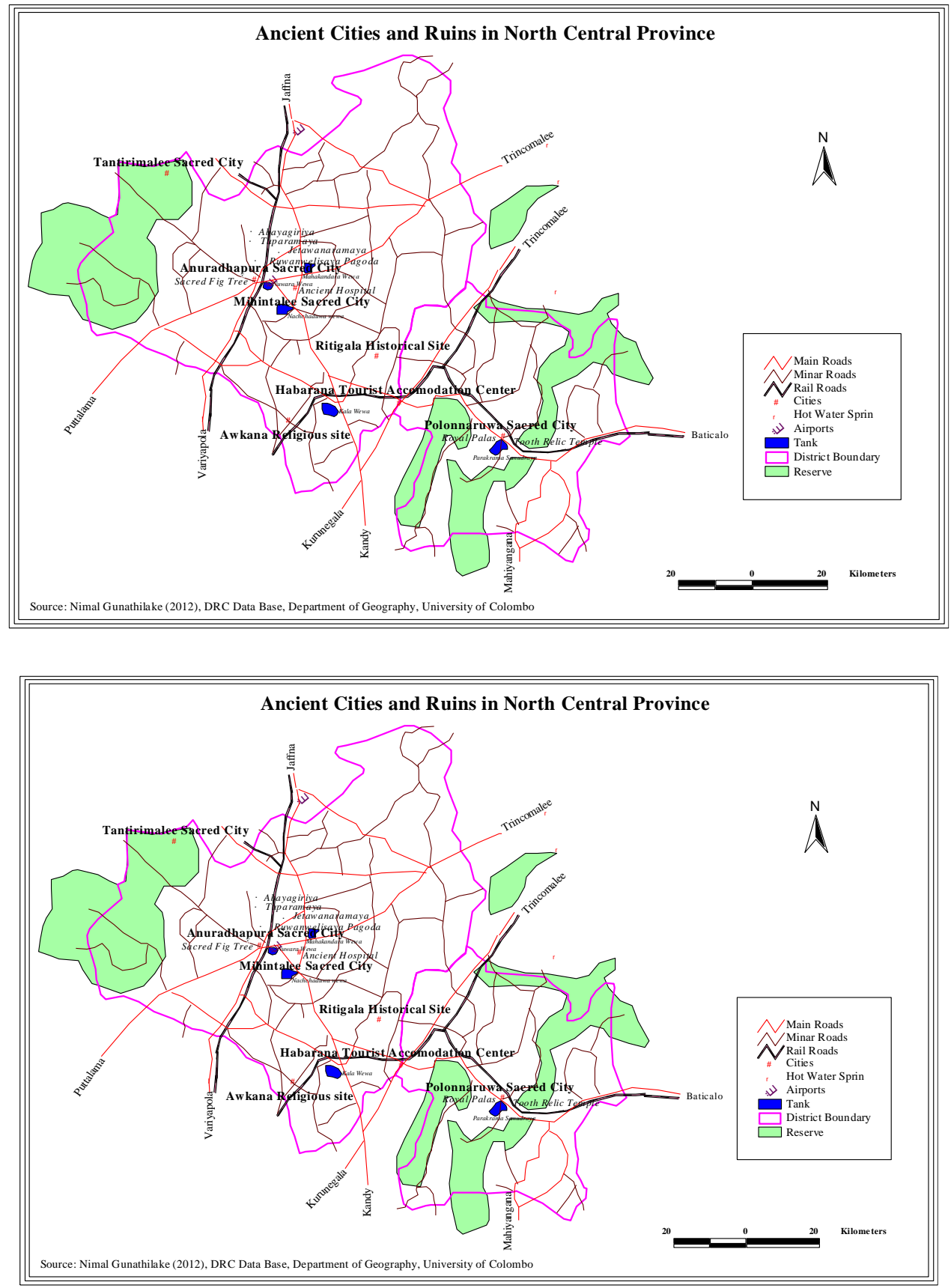

Figure 1: Ancient Cities and Ruins in North Central Province 
The city has been the capital of Sri Lanka for nearly 1400 years, and more than 120 kings ruled the island from this city using it as the center of administration. After the South Indian invasion during 1017 AD, it ceased to be the capital of the island. Sri Lanka had been ruled by nearly 196 monarchs from the first native capital from Anuradhapura to the last native kingdom of Kandy before the entire island was brought under the British rule in 1815, and well over a half of those kings ruled the country from the kingdom of Anuradhapura. The modern Anuradhapura district consists of 22 DS divisions and $694 \mathrm{GN}$ divisions (Department of Census and Statistics, 2012). It is located some $225 \mathrm{~km}$ away from Colombo city (via Dambulla).

Polonanruwa kingdom (11C AD-13C AD): This city was developed as the garrison town of the island during the Anuradhapura period itself. It became the second capital of Sri Lanka when a South Indian Chola king chose it as his center of administration after capturing Anuradhapura city in 1017 AD. Chola kept the reign of the kingdom while promoting of the worship of Hindu gods until it was re-captured by a Sri Lankan king in 1070. The Sinhalese civilization shifted from Polonnaruwa to Dambadeniya in $1232 \mathrm{AD}$ after another South Indian invasion and never came back to NCP thereafter. The modern Polonnaruwa district consists of seven DS divisions and 295 GN divisions (Department of Census and Statistics, 2012). It is located some $216 \mathrm{~km}$ away from Colombo city.

\section{CLIMATIC AND SOCIOECONOMIC CONDITIONS IN NCP}

Climatic condition in NCP is generally dry and warm although there are some variations during different seasons as it belongs to the dry areas of the island. Average annual rainy days and annual rainfall during the 2007-2011 period have been 99 and 485 millimeters respectively (Central Bank of Sri Lanka, 2011). Overwhelming majority of rainy days spread between October and January of the year. The green environment with thousands of irrigation tanks filled with water, aquatic plants and flowers such as lotus and water lily are a fascinating common scene during this rainy season. Both rain fed and irrigated agriculture practices are carried out in the province. It is the main cultivation season in the province as well as of the entire island. The temperature is low in December, January and February. 


\section{Table 3: Climatic Conditions in NCP}

\begin{tabular}{lcccccccccccc}
\hline \multicolumn{1}{c}{ Climatic factor } & Jan. & Feb. & Mar. & April & May & June & July & Aug. & Sep. & Oct. & Nov. & Dec. \\
\hline $\begin{array}{l}\text { Average Monthly } \\
\text { Rainfall (mm) }\end{array}$ & 201.8 & 96.3 & 36.7 & 113.7 & 65.8 & 21.2 & 39.6 & 77.7 & 77.4 & 216.1 & 382.4 & 323.9 \\
$\begin{array}{l}\text { Average Monthly } \\
\text { Temperature }{ }^{\circ} \mathrm{C}\end{array}$ & 25.1 & 25.8 & 27.2 & 28.6 & 29.0 & 28.7 & 28.7 & 28.0 & 27.9 & 27.3 & 26.1 & 25.1 \\
\hline
\end{tabular}

Source: Nimal Gunatilake, DRC Database, University of Colombo, 2012

The period between November and March is the main tourism season of the island and it coincides with the winter season in the northern hemisphere and perhaps the period with the best climatic condition for tourists to the island. The average temperature in the island including the NCP is low during this period. Period from December to midFebruary could be considered as the mild winter season of the island. The environmental comfort for the tourist comes naturally during the period even though somewhat rainy in the NCP during this season.

Table 4: Percentage of Population by Ethnicity and Religion-2001

\begin{tabular}{|c|c|c|c|c|c|c|c|}
\hline & \multirow[b]{2}{*}{ Location } & \multicolumn{6}{|c|}{ Ethnicity } \\
\hline & & Sinhalese & Tamil & $\begin{array}{c}\text { Sri Lankan } \\
\text { Moor }\end{array}$ & Burger & Malay & Others \\
\hline 1 & Anuradhapura District & 90.7 & 0.8 & 8.3 & -- & -- & -- \\
\hline 2 & Polonnaruwa District & 90.4 & 2.1 & 7.5 & -- & -- & 0.2 \\
\hline \multirow[t]{3}{*}{3} & Sri Lanka & 82.0 & 9.4 & 7.9 & 0.2 & 0.3 & 0.2 \\
\hline & \multirow{2}{*}{ Location } & \multicolumn{6}{|c|}{ Religion } \\
\hline & & Buddhist & Hindu & Islam & Christian & \multicolumn{2}{|c|}{ Others } \\
\hline 1 & Anuradhapura District & 90.0 & 0.5 & 8.4 & 1.1 & \multicolumn{2}{|c|}{--} \\
\hline 2 & Polonnaruwa District & 89.3 & 1.8 & 7.6 & 1.3 & \multicolumn{2}{|c|}{--} \\
\hline 3 & Sri Lanka & 76.7 & 7.8 & 8.5 & 7.0 & \multicolumn{2}{|c|}{--} \\
\hline
\end{tabular}

Source: Department of Census and Statistics, Census of Population and Housing, 2001 
Overwhelming majority of the population in the NCP and its two districts belong to Sinhalese community and Buddhist religion. The second largest community and religion in the province is Moslem while the Tamil community and Hindu religion is very small compared to the national figures. Sinhalese Buddhist culture dominates the province reflecting the historical background, so that the religious and cultural tourism in the province is about Buddhism and Buddhist (Sinhalese) culture.

Table 5: Household Income, Poverty and Expenditure Information-2009/2010

\begin{tabular}{clcc}
\hline No & Location & Mean Monthly Income (Rs.) & $\begin{array}{c}\text { Median Monthly Income } \\
\text { (Rs.) }\end{array}$ \\
\hline 1 & Anuradhapura District & 37,586 & 25,682 \\
2 & Polonnaruwa District & 31,526 & 22,634 \\
3 & North Central Province & 35,577 & 24,993 \\
4 & Sri Lanka & 36,451 & 23,746 \\
\hline No & $\quad$ Location & Poverty Headcount Index \% & Poor Household \% \\
\hline 1 & Anuradhapura District & 5.7 & 4.6 \\
2 & Polonnaruwa District & 5.8 & 4.5 \\
3 & North Central Province & 5.7 & 4.6 \\
4 & Sri Lanka & 10.8 & 9.0 \\
\hline
\end{tabular}

Source: Department of Census Statistics, Household Income and Expenditure Survey-2009/2010 Note: US\$1= Rs112.66 (2009/2010 average)

\section{RELIGIOUS AND CULTURAL TOURISM POTENTIALS IN NCP}

People travel to distant places from their place of residence to satisfy the natural curiosity of unknown behavioral patterns of unfamiliar people, their living environment, food and beverages, beliefs, rituals, historical heritage, paintings, music, dance and scholarly pursuits. The religion is instrumental in shaping and uplifting of customs, traditions, ceremonies, arts, dance, music, architecture, and values of a society. The religion and spirituality reflect the tolerance and interpersonal behavioral pattern of a society. 'There is perhaps no phenomenon as complex as culture. ... culture is everything 
in a particular society... But culture is not only a matter of music, dance, art, and cinema, for marriage customs, death rites, patterns of pilgrimage to holy cities, modes of raising children, treatment of elders, and innumerable other aspects of everyday life are stitched into the meaning of culture' (Lal Vinay, 2012).

Sri Lanka has enjoyed fame for tourism destination since antiquity mainly due to its strategic location, religious, cultural and natural attractions, spices and valuable stones. Additionally, missionary work, adventuring, treasure hunting, colonization and invasions have also contributed to this endeavor directly or indirectly. It is customary to account Ceylon's history as commencing from 544 BC on the basis that prince Vijaya, the discarded son of a royal Aryan family in Bengal, northeastern India, made a quite unexpected, but important, arrival on the island (Brohier, 1982). Apostle Mahinda, son of emperor Asoka of India, arrived in Mihintale in the North Central Sri Lanka with a group of devotees in the $3^{\text {rd }}$ century BC to propagate Buddhism. Sanghamitta nun, the sister of Apostle Mahinda, came to Anuradhapura together with a few other nuns to start fully ordained female Buddhist monastic order. She brought the right south branch of the fig tree at which Siddhartha Gautama (Buddha) attained to spiritual enlightenment to plant it in Anuradhapura (see below). The tooth relic of Buddha, now kept in the place of tooth relic in Kandy, was brought to Sri Lanka by prince Dantha and Princes Hemamala of India in the $4^{\text {th }}$ century AD, again to Anuradhapura (Geiger, 1950). Pliny the Elder (23 AD-79AD), a Roman author, naturalist, philosopher, naval and army commander also made an excellent account on Sri Lanka in the $1^{\text {st }}$ century AD.

"In the sixth book of his Natural History Pliny the Elder tours the fabled lands of the East. One of these is the distant land of Taprobane or Ceylon, which had been drawn into Mediterranean ken by the travelers and geographers of the Hellenistic Age... Pliny's account makes one of the first stages in the direct relations of Ceylon and Mediterranean; by the next century Ptolemy, in the seventh book of his Geography, demonstrates a faire acquaintance with the island." (Starr 1956: 27).

Hulugalle (1980) provided an excellent account on some 18 travelers who visited Sri Lanka in the past. Fa Hien, a Chinese Buddhist priest, visited Anuradhapura through Gobi desert, Himalayan mountain range, Nepal and India between 399 and 415 to acquire Buddhist scriptures is one of the famous travelers. Similarly, Ibn Batuta visited the Sri Paada (Adam's peak) in 1344. A Chinese admiral Ching Ho visited Sri Lanka 
twice between 1407 and 14011. Ludovico di Varhthema, an Italian traveler, visited in 1492 and Joris van Spilbergen, a Dutch admiral, met Sri Lankan king of Kandy in 1602.

Among all past visitors, Robert Knox (1660-1680) is very important because of his account on Sri Lankan society, its religions, culture and economy. He was taken prisoner by the men of the Sri Lankan king while he was on shore with other fourteen people, including his father, after their ship had dropped anchor in Trincomalee harbor, eastern Sri Lanka, because of damage caused by a storm. He lived as an open prisoner of the Kandyan kingdom in northwestern Sri Lanka, his father died nearly one year after the captivity. Knox's book An Historical Relation of Ceylon written after his return to England was first published in 1681. The book was an immediate success and Dutch, German and French translations soon followed. Knox lived in the Kandyan kingdom for nearly twenty years as a villager.

Table 6: Religious and Cultural Tourism Potentials in NCP

\begin{tabular}{|c|c|l|}
\hline \multicolumn{1}{|c|}{ Product } & \multicolumn{1}{c|}{ Description } \\
\hline i & $\begin{array}{l}\text { Pilgrimages to olden } \\
\text { religious sites }\end{array}$ & $\begin{array}{l}\text { Anuradhapura, Mihintale, Tanthirimale, Avukana, } \\
\text { Polonanaruwa, Ritigala and many other ancient locations in } \\
\text { the province are extremely useful for this purpose. } \\
\text { Additionally, there are many newly built religious attractions } \\
\text { in the province. } \\
\text { Followers of Buddhism can go on pilgrimages to those } \\
\text { locations for their spiritual and moral development/awakening. } \\
\text { They can even participate in certain religious practices along } \\
\text { with the local devotees. }\end{array}$ \\
\hline \multirow{2}{*}{ ii } & $\begin{array}{l}\text { Visiting historical sites } \\
\text { and museums }\end{array}$ & $\begin{array}{l}\text { The evidences of religious, economic, social, political and } \\
\text { military history of olden Sri Lanka have been preserved to a } \\
\text { great extent in many historical places in the province. } \\
\text { Inquisitive visitors, even though not followers, can explore and } \\
\text { learn many previously unknown facts and figures from } \\
\text { historical sites. Qualified and well-informed tour guides, site } \\
\text { booklets etc. would be useful in this endeavor. } \\
\text { There are many museums in NCP historical sites to get good } \\
\text { knowledge of those locations as well as related stories. }\end{array}$ \\
\hline
\end{tabular}




\begin{tabular}{|c|c|c|}
\hline iii & $\begin{array}{c}\text { Observing religious } \\
\text { practices }\end{array}$ & $\begin{array}{l}\text { To make an attempt to understand the true nature of the life } \\
\text { and other phenomenon, one can observe Buddhist religious } \\
\text { practices for a short period of time. } \\
\text { Popular Buddhist meditation practices can be followed while } \\
\text { visiting historical sites to develop mindfulness and improve } \\
\text { concentration. Several organizations can support this purpose. } \\
\text { Meditation cum Yoga practices is also available from certain } \\
\text { service providers. } \\
\text { The religious observing tour can be further enhanced by } \\
\text { entering into temporary priesthood for a short period of time, } \\
\text { if that facility is available. }\end{array}$ \\
\hline iv & Festivals & $\begin{array}{l}\text { Religious festivals: Month of June (Poson) is a special period } \\
\text { of festivals, ceremonies, and celebration in Anuradhapura and } \\
\text { Mihintale. In and around the full moon day of the month tens } \\
\text { of thousands of devotees flock together to these sites to } \\
\text { commemorate the introduction of Buddhism and new culture } \\
\text { to the island by apostle Mahinda from India. } \\
\text { There are some other religious festivals and processions in the } \\
\text { province linked with Buddhist monasteries or temples devoted } \\
\text { to deities on other days. } \\
\text { New year festival celebrated in mid-April is an important } \\
\text { event in the island. It carries number of religious observations, } \\
\text { rituals as well as indigenous sports, dances, and folk songs. } \\
\text { People are clad in indigenous costume and prepare traditional } \\
\text { dishes and sweets in almost every Sinhala Buddhist house } \\
\text { during the new year season. }\end{array}$ \\
\hline $\mathrm{v}$ & Ceremonies and rituals & $\begin{array}{l}\text { There are many ceremonies and rituals in the province. One of } \\
\text { them is the offering of new rice to the sacred fig tree in } \\
\text { Anuradhapura. The best part of the rice reaped in the great } \\
\text { cultivation season (Maha season) is offered to the sacred fig } \\
\text { tree in April by farmers in the province under the guidance of } \\
\text { the Buddhist monks. Farmers bring newly harvested rice in } \\
\text { small bowls and fill a large bowl kept close to the sacred fig } \\
\text { tree until it overflows. } \\
\text { Ceremonies involved with rain retreat (Vassa) of Buddhist } \\
\text { monks are performed in almost every temple in every village } \\
\text { of the province between the full moon day of July and the full }\end{array}$ \\
\hline
\end{tabular}




\begin{tabular}{|c|c|c|}
\hline & & $\begin{array}{l}\text { moon day of October. Rain Retreat is followed by Kathina, a } \\
\text { festival in which laity express their gratitude to monks by } \\
\text { offering robes and other essential items to monasteries. } \\
\text { In addition to Buddhist monasteries, there are many temples } \\
\text { dedicated to gods, goddesses, and deities throughout the } \\
\text { province. Annual/ periodical ceremonies are conducted in } \\
\text { temples dedicated to those powerful beings are part and parcel } \\
\text { of the NCP culture. They are thought to be invisible powerful } \\
\text { beings that did huge merits on donations, precepts, meditation } \\
\text { in the previous life. There had been occasions in olden days } \\
\text { when some human beings with special virtues, or } \\
\text { extraordinarily committed to the well-being of the people were } \\
\text { raised to the level of deities after their deaths and are } \\
\text { worshipped. The origin of majority of those powerful beings } \\
\text { could be traced to India. Among many others, a few old } \\
\text { monarchs are also worshipped in this manner. } \\
\text { Every important event of the life, mostly in rural areas, from } \\
\text { birth through first alphabet reading, female puberty, marriage, } \\
\text { funeral and death anniversaries are involved with religious or } \\
\text { wordily ceremonies. }\end{array}$ \\
\hline vi & $\begin{array}{c}\text { Religious cum adventure } \\
\text { tourism }\end{array}$ & $\begin{array}{l}\text { Isolated Ritigala mountain range is an ideal location for } \\
\text { mountaineering expedition cum culture/religious tourism (see } \\
\text { below). }\end{array}$ \\
\hline vii & $\begin{array}{l}\text { Study the doctrine, } \\
\text { culture, arts, history and } \\
\text { archeology. }\end{array}$ & $\begin{array}{l}\text { The province is full of olden and modern Buddhist arts, } \\
\text { architecture and craft. Olden and new stupas (pagodas), image } \\
\text { houses, sculptures, stone staircases, olden roads, byroads, } \\
\text { ponds, paintings, fortresses, ruins, and waterways are available } \\
\text { for studies and research work related to religion and culture, } \\
\text { etc. } \\
\text { There are two universities in Anuradhapura /Mihintale and one } \\
\text { of them is a dedicated institute for Buddhist studies. There is a } \\
\text { Buddhist monastery in almost every neighborhood in the } \\
\text { province with educated monks. Accommodation facilities with } \\
\text { local standards are available in many monasteries. }\end{array}$ \\
\hline
\end{tabular}




\begin{tabular}{|c|c|c|}
\hline viii & $\begin{array}{l}\text { Agro cum cultural } \\
\text { tourism }\end{array}$ & $\begin{array}{l}\text { The main livelihood of the overwhelming majority of people } \\
\text { living in the province is agriculture, mainly cultivation. } \\
\text { Agricultural practices are still surrounded by some } \\
\text { cultural/ritual practices. Great season harvesting period } \\
\text { (February, March-April) would be ideal for this purpose. }\end{array}$ \\
\hline ix & $\begin{array}{l}\text { Religion cum indigenous } \\
\text { medicine }\end{array}$ & $\begin{array}{l}\text { Indigenous medicinal (Ayurvedic) practice is closely } \\
\text { associated with the Buddhism in the province. Physical and } \\
\text { mental illnesses are treated simultaneously and effectively. } \\
\text { There are a number of famous and reliable indigenous medical } \\
\text { practitioners in the province. }\end{array}$ \\
\hline $\mathrm{x}$ & Authentic foods & $\begin{array}{l}\text { The province is famous for its own some authentic recipes of } \\
\text { dishes, confection, and staple diets even though certain food } \\
\text { items are seasonal. } \\
\text { Water lily rice (tank rice), finger millet (kurakkan) based } \\
\text { foods, food based on traditional tubers and vegetables, special } \\
\text { varieties of sweets, etc. are available from the province. }\end{array}$ \\
\hline xi & $\begin{array}{l}\text { Visiting countryside } \\
\text { (villages) }\end{array}$ & $\begin{array}{l}\text { Traditional settlements in the province have their own } \\
\text { irrigation tanks, canal systems, paddy fields, homestead and } \\
\text { gardens, Buddhist temples, veneration places for deities } \\
\text { located close to the tank, a track of forest land, shrub area for } \\
\text { shifting cultivation, and gravel roads linking villages and } \\
\text { motorways. The traditional cultural and religious aspects are } \\
\text { preserved in some villages to a great extent. }\end{array}$ \\
\hline xii & $\begin{array}{l}\text { UNESCO - Sri Lanka } \\
\text { Cultural triangle trip }\end{array}$ & $\begin{array}{l}\text { A triangular area formed by connecting historical cites of } \\
\text { Anuradpura, Pollonnarurwa and Kandy is referred to as a } \\
\text { cultural triangle. The area is covered by a number of historical } \\
\text { sites including the famous Sigiriya fortress, Dambulla rock } \\
\text { temple, Mihintale, Ritigala, Awukana, etc. in addition to three } \\
\text { connecting main historical cities. Special convenient packages } \\
\text { are offered to tourists by the private tour operators. } \\
\text { Different types of tourist accommodations are easily available } \\
\text { in the province. }\end{array}$ \\
\hline
\end{tabular}




\section{HISTORICAL LOCATIONS IN NCP: THE HIGHEST POTENTIAL FOR CULTURE AND RELIGIOUS TOURISM}

\section{a. Anuradhapura (UNESCO World Heritage):}

Anuradhapura, most sacred Buddhist religious destination, was the capital of ancient Sri Lanka from the $4^{\text {th }}$ century BC to 11 century AD. The city area spreads over 40 square kilometers. Buddhism was introduced to the island in $236 \mathrm{BC}$ by Emperor Asoka of India while King Devanampiyatissa kept this city as the capital of his kingdom. It is located some $250 \mathrm{~km}$ away from Colombo in the North Central Province. The city has enjoyed fame as one of the most extensive ruin concentrations in the world.

Most of irrigation tanks of the island were constructed in the days of the ancient kings of Anuradhapura and Polonanaruwa “...when stone-hewing seems to have been as common an employment as making earthen cooking utensils is now. The whole land is strewn with block of carved and hewn stone, and the sluices of the tanks were made of the same durable material, and remain to this day." (Administration Report, 1870).

Table 7: Selected Religious Attractions and Ruins in Anuradhapura City

\begin{tabular}{|c|c|c|}
\hline & Location & Description \\
\hline $\mathrm{i}$ & $\begin{array}{c}\text { Sacred Fig } \\
\text { Tree }\end{array}$ & $\begin{array}{l}\text { The sacred Bo (fig) tree under which Siddhartha Gautama (563 BC- } 483 \\
\text { BC) attained enlightenment (Buddha hood) is in Bodh Gaya of the current } \\
\text { State of Bihar, India. The southern branch of the same tree was brought to } \\
\text { Sri Lanka and planted in } 249 \text { BC in Anuradhapura. It is the oldest recorded } \\
\text { human planted living tree in the world now. }\end{array}$ \\
\hline ii & $\begin{array}{c}\text { Thuparama } \\
\text { Pagoda }\end{array}$ & $\begin{array}{l}\text { The first stupa (pagoda) built in Sri Lanka in the } 3^{\text {rd }} \text { century BC right after } \\
\text { receiving the Buddhism by King Devanampiya Tissa even though some } \\
\text { records maintain that Mahiyangana and Tiriyaya stupas were built during } \\
\text { the lifetime of Buddha. }\end{array}$ \\
\hline iii & $\begin{array}{c}\text { Ruvanveli } \\
\text { Pagoda }\end{array}$ & $\begin{array}{l}\text { One of the tallest stupas (pagoda) in the world standing at } 91.4 \text { meters with } \\
\text { the circumference of } 290 \text { meters built by King Dutthagamini ( } 161 \text { BC- } 137 \\
\text { BC). }\end{array}$ \\
\hline iv & $\begin{array}{c}\text { Jetavana } \\
\text { Pagoda }\end{array}$ & $\begin{array}{l}\text { This is the tallest brick-built stupa (pagoda) in the world. The paved } \\
\text { platform on which it stands covers more than } 8 \text { acres ( } 3 \text { hectares) of land. } \\
\text { The height of the stupa is } 121.9 \text { meters, the tallest in Sri Lanka and the } \\
\text { olden world. It was constructed by King Mahasena (273-301 AD) and his } \\
\text { son Maghavanna. }\end{array}$ \\
\hline
\end{tabular}




\begin{tabular}{|c|c|c|}
\hline $\mathrm{V}$ & $\begin{array}{c}\text { Abhayagiri } \\
\text { monastery and } \\
\text { Pagoda }\end{array}$ & $\begin{array}{l}\text { The monastery and the stupa (pagoda) were built by King Valagambahu } \\
\text { ( } 89-77 \mathrm{BC} \text { ). The monastery was a center of intellectuals of many branches } \\
\text { in Buddhism other than Theravada School. Fa Hien, a } 5^{\text {th }} \text { century Chinese } \\
\text { monk lived here for two years. There were some } 5,000 \text { monks living in this } \\
\text { estate during that period of time. }\end{array}$ \\
\hline vi & $\begin{array}{c}\text { Fa Hien and } \\
\text { Abhayagiri } \\
\text { Museum }\end{array}$ & $\begin{array}{l}\text { Fa Hien (Faxian), a famous Chinese Buddhist monk, visited Anuradhapura } \\
\text { around } 410 \text { AD in search of Buddhist scriptures. He lived for nearly two } \\
\text { years, mostly in Abhayagiri temple of Anuradapura city during the reign } \\
\text { of King Mahanama. Fa Hien left China in } 399 \text { AD at the age of } 65 \text { after } \\
\text { spending nearly } 14 \text { years for the trip and came back to China in } 413 \text { AD at } \\
\text { the age of } 79 \text {. On arriving home, he translated scriptures into Chinese } \\
\text { language with the help of Buddhabhandra, an Indian Buddhist monk. } \\
\text { Fa Hien seems to have visited many religiously important locations in the } \\
\text { island and also lived in different parts of the country during his stay. } \\
\text { Fahiyangala (Fa Hien's cave) located in the Kalutara district of the western } \\
\text { province of the country is considered as one of them. The monk seems to } \\
\text { have lived here for sometime on his pilgrimage to the Sri Paada (Adam's } \\
\text { Peak), so that the place was named after him. }\end{array}$ \\
\hline vii & Twin Ponds & $\begin{array}{l}\text { Two ponds built by King Aggabodhi during } 575-608 \text { AD are used by } \\
\text { Buddhist monks for bathing purpose. Two ponds are connected by a } \\
\text { pipeline at the bottom. The necessary water for ponds is supplied through } \\
\text { an underground pipeline after passing through several filtering chambers. } \\
\text { Water first enters the larger pond }(40.6 \mathrm{~m} \mathrm{X} 15.6 \mathrm{~m}) \text { through a mouth of a } \\
\text { dragon then goes to the smaller one }(28 \mathrm{~m} \mathrm{X} 15.6 \mathrm{~m}) \text {. }\end{array}$ \\
\hline viii & $\begin{array}{l}\text { Isurumuni } \\
\text { Lovers }\end{array}$ & $\begin{array}{l}\text { Isurumuniya rock temple built by King Devanam Piyatissa is famous for } \\
\text { its rock carving of two lovers. It is maintained that the carving depicts } \\
\text { prince Saliya, son of King Duttagamini, and his low cast fiancée } \\
\text { Asokamala. The prince gave up the throne because of his lover. }\end{array}$ \\
\hline ix & Brazen Palace & $\begin{array}{l}\text { This nine-storied palace was built by King Duttagamini for Buddhist } \\
\text { monks. It is also known as Lovamahapaya or lohaprasadaya in Sinhala } \\
\text { language as roof of the building was covered by bronze tiles. Historical } \\
\text { records suggest that this nine-storied building has a height of } 47 \text { meters and } \\
\text { length and width of } 46 \text { meters each side. The building was supported by } \\
1,600 \text { stone pillars. }\end{array}$ \\
\hline
\end{tabular}




\begin{tabular}{|c|c|l|}
\hline $\mathrm{x}$ & $\begin{array}{c}\text { Other } \\
\text { Important } \\
\text { Places }\end{array}$ & $\begin{array}{l}\text { Mirisawetiya stupa, seated Buddha stature, elephant pond, folk museum, } \\
\text { archeological museum, royal palaces, inscriptions and scattered ruins } \\
\text { everywhere. }\end{array}$ \\
\hline
\end{tabular}

\section{b. Mihintale (Mahinda's Hill):}

Mihintale, currently a fairly large village with some urban facilities, is situated in the North Central Province of the island, about $221 \mathrm{~km}$ from Colombo and just $12 \mathrm{~km}$ east of the UNESCO World Heritage of Anuradhapura ancient city. It is also another popular destination of Sri Lankan Buddhists as well as inbound tourists to the island. The site is also called Missaka Pabbata, Cetiyagiri or Sagiri.

Mihintale is a mountain range consisting of three main hills- Ambastala (plateau of the Mango), Rajagiri (mountain of the king) and Anaikutti (mountain of the elephant). In the $3^{\text {rd }}$ century BC Buddhism was first introduced to Sri Lanka on the mountain of Mihintale by apostle Mahinda, son of Emperor Asoka of India, to King Devanampiyatissa (307-266 BC) of Sri Lanka. This was followed by a mass conversion to Buddhism that turned Sri Lanka into one of the great Buddhist nations in the world. Buddhist devotees in large numbers gather in Anuradhapura and Mihintale on the full moon day of June every year to celebrate the introduction of Buddhism to Sri Lanka.

Table 8: Selected Religious Attractions and Ruins in Mihintale

\begin{tabular}{|c|c|l|}
\hline \multicolumn{1}{|c|}{ Location } & \multicolumn{1}{c|}{ Description } \\
\hline i & Ancient Hospital & $\begin{array}{l}\text { The ruins of an ancient hospital built by King Sena II (866-901 AD) are } \\
\text { visible at the foot of the mountain. A dug rock cavity in the shape of } \\
\text { human that was used for immersing patients in medicinal bath, circular } \\
\text { stones used for grinding medicinal herbs, and the ground plan of the } \\
\text { hospital are visible among some others in the location. Fa Hien's records } \\
\text { suggest that there was a hospital in this location while he was in Sri Lanka } \\
\text { during the } 5^{\text {th }} \text { century AD (see above). }\end{array}$ \\
\hline ii & $\begin{array}{l}\text { Stone stairway } \\
\text { to the mountain }\end{array}$ & $\begin{array}{l}\text { Elegantly carved and paved 1,840 granite rock steps take visitors from } \\
\text { bottom to the top of the mountain. All the way is shaded by frangipani } \\
\text { trees. }\end{array}$ \\
\hline iii & Kantaka Chetiya & $\begin{array}{l}\text { Kantaka Chetiya, a stupa, built by King Suratissa in the } 1^{\text {st }} \text { century BC is } \\
\text { visible on halfway through to the mountain on the right side. It is 40 feet } \\
\text { in height and 425 feet in circumference. The stupa is famous in Sri Lanka } \\
\text { due to its special architectural features. }\end{array}$ \\
\hline
\end{tabular}




\begin{tabular}{|c|c|l|}
\hline iv & $\begin{array}{c}\text { Mango tree } \\
\text { stupa }\end{array}$ & $\begin{array}{l}\text { Ambasthala (mango tree) stupa was built over the ashes of Arahat } \\
\text { Mahinda who surprised King Devanampiyatissa on the same spot and } \\
\text { quizzed him to test his intelligence before preaching a sutra to him. It is } \\
\text { located on the plain close to the summit of the rock. }\end{array}$ \\
\hline v & $\begin{array}{c}\text { Aradhanagala } \\
\text { (Rock of } \\
\text { convocation) }\end{array}$ & $\begin{array}{l}\text { Located at the top of the mountain where sage Mahinda stood with his } \\
\text { disciples and called to King Devanampiyatissa who was chasing a deer. }\end{array}$ \\
\hline vi & $\begin{array}{c}\text { Rock caves } \\
\text { vii }\end{array}$ & $\begin{array}{c}\text { Othere are over 60 rock caves used by Buddhist monks in the ancient time. } \\
\text { monuments }\end{array}$ \\
\hline Evidence suggests that one of them was used by the sage Mahinda. \\
\hline meditation seats, relic houses, assembly halls, pavilions and museum. \\
\hline
\end{tabular}

\section{c. Polonnaruwa:}

The second largest ancient city next to Anurahapura is located in the NCP some 221 $\mathrm{km}$ from Colombo. It is also the second capital of Sri Lanka after destruction of Anuradhapura in 993 by invaders.

Table 9: Selected Religious Attractions and Ruins in Polonnaruwa

\begin{tabular}{|c|c|l|}
\hline Location & \multicolumn{1}{c|}{ Description } \\
\hline i & $\begin{array}{c}\text { The Royal } \\
\text { Palace }\end{array}$ & $\begin{array}{l}\text { Ruins of five-story building with signs of all facilities to meet the needs of } \\
\text { a monarch of the day. Ruins and historical records suggest that the building } \\
\text { consisted of separate queen chambers, bathing places, official quarters, } \\
\text { dinning rooms with kitchens, and parks. The compound was surrounded } \\
\text { by a wide rampart with watch towers, turrets, and walks. The complex was } \\
\text { built by King Parkramabahu I in the 12 }\end{array}$ \\
\hline ii & $\begin{array}{c}\text { The } \text { Sentury. } \\
\text { Storied } \\
\text { Building }\end{array}$ & $\begin{array}{l}\text { Sathmahal Prasada (seven-storied building) with a staircase leading to } \\
\text { upper levels is an unusual pyramid-shaped stupa to Sri Lanka although this } \\
\text { pattern is common in Thailand and Cambodia. It was made out of brick } \\
\text { and is over 9 meters in height. It is maintained that this was built to use as } \\
\text { the worship place of Cambodian soldiers working under the king. }\end{array}$ \\
\hline iii & $\begin{array}{c}\text { Tooth Relic } \\
\text { Temple }\end{array}$ & $\begin{array}{l}\text { Atadage (house of eight relics), the first tooth relic temple of the kingdom, } \\
\text { was built by King Vijayabahu in the 11th century. Nearly 54 stone pillars }\end{array}$ \\
\hline
\end{tabular}




\begin{tabular}{|c|c|l|}
\hline iv & $\begin{array}{l}\text { of the building with inscriptions of Sinhala and Tamil are visible today. A } \\
\text { big Buddha statue in 3 meters high is also visible near the end of the temple. }\end{array}$ \\
\hline v & $\begin{array}{c}\text { Monastic } \\
\text { Educational } \\
\text { Complex } \\
\text { Gal Viharaya (stone shrine) is one of the most admired and venerated place } \\
\text { in the country consisting of stone statues of Buddha in all major postures- } \\
\text { standing, seated, and recumbent. }\end{array}$ & $\begin{array}{l}\text { Alahana Pirivena (monastic educational institute) founded by King } \\
\text { Parakramabahu I in the 12 } \\
\text { the kingdom. The recent excavations suggest that the complex consisted of } \\
\text { a special hospital for monks in addition to educational facilities. }\end{array}$ \\
\hline vi & $\begin{array}{c}\text { Pagoda with a } \\
\text { Golden } \\
\text { Pinnacle }\end{array}$ & $\begin{array}{l}\text { Rankoth Vehera (Pagoda with golden pinnacle) with stone paving and } \\
\text { gateways constructed by King Nissankamalla. }\end{array}$ \\
\hline vii & $\begin{array}{c}\text { Hindu Shrines } \\
\text { and } \\
\text { Monuments }\end{array}$ & $\begin{array}{l}\text { About 14 Hindu shrines in the ancient city testify the South Indian } \\
\text { influence in the kingdom. The Shiva shrine and the sculpture of God Shiva } \\
\text { and Partvati standing together are the most frequently visited attraction of } \\
\text { those monuments. }\end{array}$ \\
\hline viii & $\begin{array}{l}\text { Other } \\
\text { monuments }\end{array}$ & $\begin{array}{l}\text { Latha Mandapa (flower scroll halls), council chamber, statue of sage, } \\
\text { sacred quadrangle, image houses, pagodas, pavilions, library, 9-meter long } \\
\text { stone slab etc... }\end{array}$ \\
\hline
\end{tabular}

\section{d. Ritigala (Arittha Pabbata):}

Ritigala, the highest isolated mountain range consisting of four peaks in the vast northern dry plain of Sri Lanka, lies just $43 \mathrm{~km}$ away from the historical city of Anuradhapura. The highest point of the mountain range is $766 \mathrm{~m}$ above sea level and $600 \mathrm{~m}$ above the surrounding plains and nearly $4.8 \mathrm{~km}$ long. It spreads over 1,582 hectares $(3,776$ acres $)$ and is a highly protected nature reserve with distinctive biodiversity. This rare location is an excellent destination for both culture and eco- tourism. Upper parts of mountains are covered with clouds and mists during rainy season (October to January) and from evening to morning even in many dry days. The temperature is cooler and the moisture is higher in the upper parts of the mountains contrast to the surrounding dry plains of the bottom. The mountains are home to lush vegetation and multitude of creatures. 
The ruins of a monastery built during the $1^{\text {st }}$ century BC scattering over an area of 24 hectares (59 acres) are visible in the location. There are some 70 odd caves used by meditating monks during the $1^{\text {st }}$ century $\mathrm{BC}$ and early centuries of the Common Era. Among others, there are olden paths with pavements, inscriptions, decorated urinals consisting of urine cups, drain holes and foot supports, and broken man made reservoir to store water for drinking and bathing needs of meditating monks.

The Ramayana, an Indian epic compiled in the $4^{\text {th }}$ century BC, refers the island as Lanka as the fortress of powerful demon King Ravana who captured the wife of Rama, an incarnation of the Hindu God Vishnu. The epic says further that Hanuman, a mighty monkey deity, leapt over to Lanka and destroyed its capital by fire and leapt back to India from the Ritigala Mountain to inform Rama that his wife Sita had been found in Sri Lanka.

It is strategically located between Anuradhapura and three nearby major tourist attractions (Polonanruwa, Sigiriya and Dambulla) and just a few minutes away from the popular tourist resort of Habarana.

\section{e. Tanthirimale:}

Tanthirimale, an important Buddhist religious place in the province, is located some $40 \mathrm{~km}$ away from the holy city of Anuradhapura. Folklore suggests that Prince Saliya, a discarded son of King Duttagamini, married a low-cast girl called Ashokamala and lived in this village for years before being forgiven (see above Isuruminya lovers). The king gave them a golden necklace resembling a shape of local butterfly called 'Tanthiri'. The necklace is called Male in Sinhalese language and the place name 'Tanthirimale' was coined by joining two words -Tanthiri and Male- together. It is said that in the past this location was also called as Thivakka Bamunugama (the village of Thivakka Brahmin) as it was under his control.

The location is believed to be used as a resting place by procession led by Buddhist nun Sanggamitta, daughter of Emperor Asoka, while it was heading to Anuradhapura city with a sampling of Sri Maha bo tree after arriving at the Dambakola Patuana (Dambakola port).

The sacred location spreads over 300 acres and it consists of the following religiously important objects.

(i) Sacred Bo tree flourishing on the rock space: This tree is believed to be one of the eight scared Bo samplings received from Bo tree of Bodh Gaya of India. As a mark of 
appreciation in providing accommodation on its way to Anuradhapura, an offshoot of Bo sampling was planted here by the procession led by nun Sanggamitta.

(ii) Ancient Buddha statues: there is a 15-meter long reclining statue and a 2.16-meter high seated statue.

In addition to those two sacred places, there are olden buildings and caves with pre historic paintings, incomplete granite carvings and many historical ruins in this location.

\section{f. Avukana Buddha Statue:}

The $5^{\text {th }}$ century 12-meter standing Buddha statue, carved out of a large granite face, is located in Avukana village, some $50 \mathrm{~km}$ from Anuradhapura city. This 'blessing posture' statute is not completely separated form the granite and a narrow strip is left at the back of the statue to support it. The pedestal of one meter high on which the statue stands is carved out in the form of a double petal lotus flower. The total height of the statue with its lotus pedestal is 13 meters. The robe of the statue is worn tightly outlining the shape of the body. It is maintained that the statue reflects the influence of Indian Gandhara and Amaravathi schools of art.

\section{CONCLUSION}

Sri Lanka is a tropical island with an exceptional biodiversity, beautiful wide beaches fringed with coconut groves, a rich cultural heritage, a multireligious and multiethnic society, friendly people with smiling faces, mouth-watering spicy foods, succulent tropical fruits and many varieties of vegetable. Although the island has a small population, it is rich in four major religions and cultural diversity with an immense attraction to tourists. Buddhism is the main religion of the overwhelming majority of people even though Hinduism, Christianity and Islam are practiced side by side. The rich cultural heritage rotating around the religious practices, tolerance and beliefs ranges from historical monuments and ancient cities through meditation, yoga, folk music and dance, ceremonies, rituals, authentic foods and beverages, traditional agriculture, traditional costumes, indigenous medicine and healing methods, art, and traditional sports. NCP has enjoyed fame for its centuries-old Buddhism rooted culture to promote religious and cultural tourism.

The better socioeconomic conditions, tourist-friendly community, fairly developed infrastructural facilities and quality accommodations of the province are instrumental in promoting tourism. Dedicated and well-equipped service providers with excellent past track records are also an added advantage in this endeavor. A few locations in the 
province are well-known among tourists while some other locations such as Ritigala and Tanthirimale have not received their due attention so far. Similarly, new tourism products such as culture cum adventure and culture cum agro tourism can be promoted in the province.

The community participation, especially advisory role of the priesthood in the province is essential in culture and religious tourism. The historical and cultural heritage should be essentially preserved in their pristine form while guaranteeing the satisfaction of the tourist. A concerted effort with the participation of the priesthood, community, public officials, and service providers are necessary in this effort. A certain percentage of profits from the industry should go to the community, and certain target products can be introduced for this purpose. Even though the Buddhism and Sinhalese culture is the mainstream of the province, other religions and cultures are practiced freely side by side. It is possible to organize multicultural events to develop the feelings of collective ownership and responsibility of tourism products among all communities

\section{References}

Administration Reports (1870), District of Nuwarakalawiya, CO: 57/51/1870, Public Record Office, London

An Officer, Late of the Ceylon Riffles (1876), Ceylon: A General Description of the Island, Historical, Physical, Statistical, vol. ii. Campton and Hall, London.

Ariyapala, M.B. (1956), Society in Mediaeval Ceylon (The State of Society in Ceylon as depicted in the Saddharma-ratnávaliya and other Literature of the Thirteenth Century), Department of Cultural Affairs, Colombo, (1968)

Bertolacci, Anthony (1817), A View of the Agricultural, Commercial and Financial Interests of Ceylon, Tisara Prakasakayo, Dehiwala, Sri Lanka, (1983)

Brohier, R.L. (1982), Discovering Ceylon, Lake House Investments Ltd., Colombo, Sri Lanka

Buddha Dharma Education Association Inc. http://www.buddhanet.net

Central Bank of Sri Lanka, Annual Reports, Colombo

Central Cultural Fund, http://www.ccf.lk

Codrington, H.W.( 1926), A Short History of Ceylon, Macmillan and Co. Ltd., London

Coomaraswamy, Ananda K. (1913), The Arts and Crafts of India and Ceylon, T. N. Foulis, London

Coomaraswamy, A.K. (1908), Mediaeval Sinhalese Art, Kelmscott, Essex House Press, London

Daily News, http://www.dailynews.lk

Department of Census Statistics (2010), Household Income and Expenditure Survey-2009/2010, Colombo 
Department of Census and Statistics (2001), Census of Population and Housing-2001, Colombo de Silva, Chandra Richard (1987), Sri Lanka: A History, Sangam Books Limited, London.

Elliott, Charles Brooke (1938), The Real Ceylon, H. W. Cave \& Co., Colombo.

Ferguson, John (1903), Ceylon in 1903: Describing the Progress of the Island since 1803, its Present Agricultural and Commercial Enterprises, and its Unequalled Attraction to Visitors, A. M. \& J. Ferguson, Colombo

Geiger, Wilhelm (1950), The Mahávamsa (trans.), The Ceylon Government Information Department Hettiaratchi, S.B. (1974), "Social Conditions in Ceylon (c. A.D. 300-1000)", Thesis submitted for the Degree of Doctor of Philosophy, University of London

Hulugalle, H.A.J. (1965), Ceylon of the Early Travellers, I. G. M. Limited, Colombo, (1980).

Kariyawasam, A.G. S. (1995), The Gods and Deity Worship in Sri Lanka, The Wheel Publication, Kandy

Knighton, William (1845), The History of Ceylon, Studies on Sri Lanka Series No. 16, Sri Sataguru Publications, Delhi, India, 1993

Knox, Robert (1681), An Historical Relation of Ceylon, Tisara Prakasakayo Ltd., Dehiwala, Sri Lanka, 1981

Lal Vinay (2012), “Culture”, http://www.sscnet.ucla.edu/southasia/Culture/culture.html

Marshall, Henry. M.D. (1846), “Ceylon: A General Description of the Island and of its Inhabitants", The Ceylon Historical Journal, vol.xv, Tisara Prakasakayo, Dehiwala, Ceylon, 1969 (full volume)

Mendis, G. C. (1957), Ceylon Today and Yesterday: Main Currents of Ceylon History, The Associated Newspapers of Ceylon Ltd., Colombo, 1963

Mendis, G. C. (1948), Ceylon under the British, The Colombo Apothecaries' Co., Ltd., Colombo

Mills, Lennox A. (1933), Ceylon Under the British Rule, 1795-1932, With an Account of the East India Company's Embassies to Kandy 1762-1795, Oxford University Press, London

Parker, H. (1909), Ancient Ceylon, Asian Educational Services, New Delhi, 1981

Percival, Robert (1803), An Account of the Island of Ceylon, Gregg International Publishers Limited, Hants, England, (1972)

Perera, Arthur A. (1917), Sinhalese Folklore: Ceylon, The British India Press, Mazgaon, Bombay

Perera, B. J. (1951), "The Foreign Trade and Commerce of Ancient Ceylon: I. The Ports of Ancient Ceylon", The Ceylon Historical Journal, vol.1, no.2, pp. 109-118

Perera, Arthur A. (1917), Sinhalese Folklore: Ceylon, The British India Press, Mazgaon, Bombay

Pieris, Ralph (1956), Sinhalese Social Organization: The Kandyan Period, The Ceylon University Press Board, Colombo

Ranaweera, Munidasa P. (2004), "Ancient Stupas in Sri Lanka- Largest Brick Structures in the World”, CHS News Letter, No.70, December 2004, London Construction History Society

Sarkar, N.K. \& Tambiah, S.J. (1957), The Disintegrating Village: Report of a Socio-Economic Survey Conducted by the University of Ceylon, Part I. The Ceylon University Press 
Sirr, Henry Charles (1850), Ceylon and the Cingalese; Their History, Government and Religion, the Antiquities, Institutions, Produce, Revenue, and Capabilities of the Island with Anecdotes Illustrating the Manners and Customs of the People, vol. i \& ii, Gregg International Publishers Limited, Hants, England, (1972)

Tennet, Sir James Emerson (1859), Ceylon, vol. I, Longman, London, 1860

Sri Lanka Holidays \& Sri Lanka Tours, http://www.mysrilankaholidays.com

Sri Lanka Tourism Development Authority, http://www.sltda.lk

Star, Chester G. (1956), 'The Roman Emperor and the King of Ceylon', Classical Philosophy, vol.51, no. 1, The University of Chicago Press

Wimalaratana, W. (2011), Agriculture and Rural Development in Sri Lanka: S.M.P. Senanayake Feliciation volume (Ed.), Department of Economics, University of Colombo

Wimalaratana, W. \& D.A.C. Silva (2009), "Community Based Sustainable Tourism: A Case Study of the Moneragala District”, Sri Lanka Jouranal of Agraian Studies, Vol.13, No1

Wimalaratana, W. (2008), "Household Consumption in Olden Sri Lanka", Growth and Development Perspectives in Sri Lanka A Festschrift in Honor of W.D. Lakshman, pp 311 - 345, Department of Economics, University of Colombo

Tantiirimale Rajamaha Viharaya, http://www.tantirimale.net

Tipitaka Network, http://www.tipitaka.net

UNDP (2011), "Sustainability and Equity: A Better Future for All”, Human Development Report, New York

UNESCO, "Sacred City of Anuradhapura”, http://whc.unesco.org/en/list/200/ 